\title{
A MORAL DO RISO EM BERGSON
}

\section{GEOVANA DA PAZ MONTEIRO ${ }^{1}$}

RESUMO: O artigo aborda elementos para a compreensão de uma moral social no pensamento do filósofo francês Henri Bergson (1859-1941), a partir da obra de 1900, O riso, em diálogo com algumas idéias apresentadas em seu último livro, As duas fontes da moral e da religião. Em auxílio à nossa interpretação, faremos o cotejo com alguns textos de Sigmund Freud referentes à cultura e o comportamento humano em sociedade em fina sintonia com as ideias de Bergson. Embora $O$ riso se pretenda um ensaio acerca da comicidade, o conteúdo da obra extrapola o campo de um mero estudo acerca do cômico nos entregando uma profunda reflexão estética sobre o valor da arte, além de uma crítica implícita à ciência através do confronto com outras teorias clássicas do riso. Todavia, o que nos interessa no momento é o destaque insistente dado por Bergson à função social que o ato de rir comporta. O riso seria uma espécie de ferramenta de ajuste dos comportamentos sociais. Suspeitamos, enfim, que haja naquela obra elementos para se pensar uma sociologia bergsoniana em estado embrionário, cujo desenvolvimento mais robusto só veremos nascer 32 anos mais tarde, com a publicação d'As duas fontes.

PALAVRAS-CHAVE: Riso; Moral; Sociedade; Bergson; Freud.

ABSTRACT: The paper discusses elements for the understanding of a social moral in the thought of the french philosopher Henri Bergson (1859-1941), from the 1900 work, The laughter, in dialogue with some ideas presented in his last book, The two sources of morality and religion. To aid our interpretation, we will compare them with some texts by Sigmund Freud about culture and social human behavior in fine harmony with Bergson's ideas. Although The laughter is intended as an essay on comicality, the content of this book goes beyond the scope of a mere study of the comic, giving us a deep aesthetic reflection on the value of art, in addition to an implicit criticism of science through confrontation with other classic theories about laughter. However, what interests us at the moment is the insistent emphasis given by Bergson to the social function that the act of laughing has. The laughter would be a kind of tool for adjusting social behaviors. We have the suspicion that there is in that book elements to think about a bergsonian sociology in an embryonic state, whose more robust development we will only see born 32 years later with The two sources.

KEYWORDS: Laughter; Moral; Society; Bergson; Freud.

Uma obra composta a partir da reunião de três ensaios publicados separadamente na Revue de Paris, em 1899, esta é O riso (2001), de Henri Bergson. À primeira vista, um escrito sobre "[...] os processos de fabricação da comicidade" (BERGSON, 2001, p. VII), como o

\footnotetext{
${ }^{1}$ Professora adjunta do colegiado de filosofia do Centro de Formação de Professores Universidade Federal do Recôncavo da Bahia (UFRB). Doutora em filosofia pela Universidade Federal da Bahia (UFBA). E-mail: geovana@ufrb.edu.br.
} 
próprio subtítulo nos deixa antever. No entanto, um escrutínio mais atento daquela obra poderia revelar muito mais que um simples estudo sobre o cômico, revelaria, enfim, uma análise do comportamento humano em sociedade.

Movida pelo rastro bergsoniano, buscarei aqui abordar alguns aspectos que apontem, desde $O$ riso, para a análise futura de uma moral fechada, em paralelo à sua organização social correspondente, as quais somente veremos esclarecidas na obra de 1932, As duas fontes da moral e da religião (2005). Algumas ideias apresentadas por Sigmund Freud em textos sobre cultura e sociedade, como $O$ mal-estar na civilização (2014) e O futuro de uma ilusão (2014a), também virão em auxílio à nossa discussão. O próprio autor, na obra $O$ chiste e sua relação com o inconsciente (2017), publicada em 1905, cita por diversas vezes e elogiosamente $O$ riso, concordando em muitos pontos com as ideias de Bergson sobre a comicidade resultante da "“[...] degradação do ser vivo em inanimado" (FREUD, 2017, p. 296). ${ }^{2}$

A temática da comicidade e sua dimensão social é cara a Bergson desde muito cedo. Em 1884, aos 25 anos, ele profere a palestra intitulada “O riso. Do que rimos? Por que rimos?", em Clermond-Ferrand (MINOIS, 2003, p. 520). Desde então, podemos observar como o elemento social está presente, para o filósofo, em todas as esferas humanas, o que se esclarecerá n'As duas fontes como um fator biológico, natural à espécie (BERGSON, 2005, p. 89). ${ }^{3}$ Neste último livro, Bergson elabora de modo mais aprofundado sua compreensão da sociedade, mas podemos perceber que os traços de sua "sociologia"4 já estavam contidos implicitamente no ensaio publicado em $1900 .^{5}$

A ideia do riso como um gesto social, ferramenta de ajuste dos comportamentos humanos, traz em si o germe da crítica de Bergson à moral da pressão e à estrutura fechada das sociedades, em paralelo à manutenção das normas e padrões de comportamento coletivo. A fim

\footnotetext{
${ }^{2}$ Há interessantes pontos de convergência entre $O$ chiste, de Freud, e $O$ riso, de Bergson, no que tange aos mecanismos de produção do cômico. Entretanto, esse não é o foco da nossa discussão neste artigo. Nosso interesse aqui se volta para a questão social envolvida no ato de rir. Deste modo, as obras sociais de Freud serão mais pertinentes à nossa análise no momento.

${ }^{3} \mathrm{O}$ interesse de Bergson pelo fator social que envolve o riso pode ter sua origem nos trabalhos de Durkheim, de quem o filósofo foi contemporâneo na École Normale, como nos diz Minois: "Em 1897, Durkheim publica $O$ suicídio, mostrando que esse gesto é consequência do rompimento do feixe das solidariedades sociais. Três anos mais tarde, Bergson publica $O$ riso, no qual, de certa forma, este é a contrapartida do suicídio: é a reação inconsciente que visa manter a homogenia do tecido social sancionando os desvios de comportamento" (MINOIS, 2003 , p. 521)

${ }^{4}$ Por "sua sociologia" compreendemos as reflexões de Bergson acerca do comportamento humano em sociedades. (Cf. SIBERTIN-BLANC, 2011)

${ }^{5}$ A análise de Guillaume Sibertin-Blanc (2011, p. 66) ressalta que o estudo bergsoniano sobre o cômico toca, sobretudo, o fato de que a ordem social é imanente às diversas esferas do humano, a saber, a esfera corporal, psíquica, lingüística, intelectual e cultural. E destaca uma contradição visível no próprio seio da regulação social: "a sociedade, pelo riso, 'corrige' o que ela mesma suscita, e utiliza isto que ela suscita para se retificar" (SIBERTIN-BLANC, 2011, p. 66, tradução livre).
} 
de aprofundarmos esta interpretação d' $O$ riso, livro por vezes esquecido entre os intérpretes do bergsonismo, formulamos algumas perguntas que deverão nos guiar nesta investigação, a saber: o que implica a afirmação do riso como um gesto social? De que modo tal afirmação se relaciona com a noção de moral fechada apresentada na obra de 1932? Por fim: como o ensaio de 1900 se insere no fluxo geral da filosofia de Bergson e na história do pensamento?

Para traçarmos um paralelo entre os dois livros, tão distantes na cronologia das obras bergsonianas, mas tão conectados pela experiência temporal do próprio filósofo e de seu filosofar, precisamos partir da breve análise de algumas ideias apresentadas n'As duas fontes. Ali o autor defende que a faculdade intelectual nos humanos, tal como o instinto nos animais não-humanos, conduz naturalmente a espécie a organizações fechadas. ${ }^{6}$ Em tais sistemas de vida social, a fim de garantir razoável e confortavelmente sua sobrevivência, os seres humanos partilham de uma moral fechada que os pressiona, com o auxílio das instituições, notadamente da religião, à manutenção da ordem, de padrões de comportamento aceitáveis e previsíveis. Essa moral fechada se caracteriza pela obrigação que é, em alguma medida, fruto da educação pelo hábito, ou seja, do adestramento. O hábito é fundamental nesse processo, haja vista o fato de que um organismo social, ao contrário de um organismo vivo, é composto por indivíduos livres, com vontades e interesses diversos, dos quais abrem mão em nome da segurança que a vida em sociedade poderia lhes proporcionar (BERGSON, 2005, Cap. 1).

Mas essa tendência a obedecer, no âmbito de uma organização social, presente tanto nas espécies menos evoluídas, formigas e abelhas, por exemplo, quanto em nós, seres racionais, é descrita por Bergson como possuindo um caráter vital. Ou seja, seríamos biologicamente obedientes e sociáveis em vista de nossa conservação como espécie (BERGSON, 2005, p. 89). É para um fechamento orgânico que a evolução da vida aponta, tanto instintiva quanto intelectualmente. Tal fechamento, portanto, se constataria em toda parte no mundo vivo. Buscando mecanismos de sobrevivência, os organismos se adaptaram às condições do meio de maneiras diversas. Seria então mais prático ao ser humano buscar uma organização social fechada. Não esqueçamos, a inteligência é uma faculdade prática, ela insere os indivíduos nas escolhas mais úteis a fim de garantir, além de sua sobrevivência, conforto. ${ }^{7}$ Poderíamos afirmar então que uma sociedade fechada e sua moral decorrente sejam naturais à espécie humana como

\footnotetext{
${ }^{6}$ Para aprofundar a concepção bergsoniana de evolução, vale conferir sua obra A evolução criadora (BERGSON, 2005a), onde o filósofo explora o desenvolvimento das tendências divergentes do elã vital.

${ }^{7}$ É necessário esclarecer também que quando falamos em sociedades fechadas estamos nos referindo a pequenos grupos que trabalham por um objetivo em comum. Pode ser uma pequena comunidade, uma cidade, um estado, no máximo um país. Não nos referimos aqui à humanidade como um todo. Esta ressalva será importante para as consequências que a manutenção da moral fechada pode engendrar, a saber, no limite, o estado de guerra.
} 
mecanismo de autoproteção. Dito isso, podemos agora indagar: em que o riso decorrente de situações cômicas poderia auxiliar esses mecanismos sociais de manutenção da ordem?

\section{O riso como um gesto social}

O leitor é conduzido n'O riso pela suspeita de que "[...] a invenção cômica [...] nos daria informações sobre os procedimentos de trabalho da imaginação humana e, mais particularmente, da imaginação social, coletiva, popular" (BERGSON, 2001, p. 2). A comicidade seria então produto da arte, mas também da vida, porque brota do convívio social, das interações cotidianas. Daí concluir-se não haver comicidade fora do domínio humano. Apenas um ser inteligente, além de poder rir, será capaz de fazer rir. É necessário frisar, contudo, que na obra de 1900 Bergson trata do riso decorrente de situações cômicas, não do riso em geral. Afinal, bem sabemos, o riso pode ser a expressão de muitos sentimentos, cujo aprofundamento não nos caberá no momento.

Da constatação, aparentemente simples, de que apenas seres inteligentes são capazes de rir e de fazer rir, decorrerá outra deveras importante para o propósito de compreender o riso como um gesto social, qual seja, a ideia de que tal gesto venha sempre acompanhado por certa "insensibilidade" do espírito. "O riso não tem maior inimigo que a emoção" (BERGSON, 2001, p. 3). Ora, seria improvável rirmos de uma situação cômica caso estivéssemos nela envolvidos diretamente. Ainda que pudéssemos rir de alguém por quem tenhamos alguma afeição, ou mesmo que nos desperte sentimentos de compaixão ou piedade, por exemplo, o riso parece surgir apenas quando, por alguns instantes, estejamos indiferentes a tais sentimentos. A comicidade, dirá Bergson, “[...] exige enfim algo como uma anestesia momentânea do coração. Ela se dirige à inteligência pura" (BERGSON, 2001, p. 4).

Bem notou Sibertin-Blanc (2011, p. 68) que

\footnotetext{
a relação dos ridentes com o objeto risível encontra seu fator essencial em uma ruptura da simpatia, uma distância que é uma indiferença, e que faz do sentimento do cômico uma emoção ela mesma contraditória: uma emoção insensível, se assim podemos dizer. (tradução livre)
}

Logo, é importante compreendermos que a comicidade, ou o sentimento decorrente de situações cômicas que levam ao riso, não deixa de ser uma forma de emoção, um modo de ser movido por uma experiência temporal, não obstante Bergson afirme em 1900 que a emoção se apaga ao presenciarmos situações cômicas. Ocorre que no domínio do cômico a emoção em questão não implica simpatia com o objeto do riso, mas antipatia, uma desconexão completa com tal 
objeto, daí sua “contradição". A fim de aprofundarmos a relação do riso com a emoção caberá aqui uma breve digressão.

Toda a obra bergsoniana é perpassada por uma peculiar compreensão desse estado da alma. Poderíamos até mesmo afirmar: Bergson é o filósofo da emoção (FENEUIL; WATERLOT, 2017, p. 51-60). Dissemos aqui que ela é ausente em situações cômicas, e isso trará sérias complicações para a legitimação da comédia como forma de arte autêntica. Pois, se a arte, assim como a filosofia, é produto de uma "emoção criadora", de uma intuição, uma vez que a comédia derive de situações em que a emoção se cala, de onde esta retiraria seu valor de arte $?^{8}$

É no contexto d'As duas fontes que o filósofo apura a sua tese sobre a emoção. Lá encontramos uma interessante distinção entre emoções supra e infra-intelectuais (BERGSON, 2005, p. 50). De fato, considerando essa distinção apresentada em 1932, seria então outro tipo de emoção a nascer de experiências cômicas, a saber, uma emoção infra-intelectual, superficial, efeito direto de uma situação a ser corrigida. Uma emoção criadora, por sua vez, é supraintelectual, está para além do domínio da racionalidade espacializante. Obviamente, não se pode dispensar a inteligência no domínio da criação, porém seria uma emoção profunda a verdadeira base das grandes criações da humanidade (SCHICK, 2017, p. 161). Então, quando pensamos na comédia como uma forma de arte que possui um papel social, é para o campo das emoções infra-intelectuais que nos voltamos, campo este que nos remete ao passado, a lembranças de situações corriqueiras.

Todavia, a distinção crucial entre uma emoção supra-intelectual e outra infra está no fato de que a primeira nunca é efeito, é sempre a causa. O riso cômico surge em decorrência de alguma situação presenciada, de uma fisionomia destoante, da observação de um desajuste, enfim, o riso, nestes casos, é sempre efeito. Deste modo, o sentimento do cômico seria um abalo superficial da alma. Uma emoção criadora, por outro lado, é sempre causa, dela vem o impulso para a criação do novo, é, enfim, uma experiência de originalidade que não sobrevém por intermédio do que quer que seja. (Cf. BERGSON, 2005, p. 50). Em suma, uma emoção criadora é uma intuição, uma experiência profunda da duração, e por isto mesmo irredutível a qualquer funcionalidade prática. $\mathrm{O}$ riso, no entanto, no âmbito da sociedade, possui uma função prática, como pretendemos mostrar logo adiante.

\footnotetext{
${ }^{8}$ Para maiores aprofundamentos sobre o problema do valor da arte e a questão estética em Bergson, vale conferir o Capítulo III d'O riso.
} 
Voltando agora ao centro da discussão: já não veríamos nessa primeira constatação, a de que o riso seja acompanhado de uma insensibilidade momentânea do espírito, traços da noção de moral fechada a ser futuramente apresentada n'As duas fontes? A moral fechada é a moral da inteligência, moral prática que prima pela manutenção da ordem, da garantia da sobrevivência e dos interesses do grupo. Conforme notou o filósofo, "o homem faz corpo com a sociedade; ele e ela estão conjuntamente absorvidos numa mesma tarefa de conservação individual e social" (BERGSON, 2005, p. 45). Este ambiente social é o lugar natural do riso. Assim: "não saborearíamos a comicidade se nos sentíssemos isolados. Parece que o riso precisa de eco [porque] nosso riso é sempre o riso de um grupo" (BERGSON, 2001, p. 4-5). ${ }^{9}$

Certamente cada um de nós deve recordar-se de, no mínimo, uma situação constrangedora quando, ao ouvirmos uma anedota, não rimos por não estarmos inseridos no contexto da situação representada, ou seja, não compreendemos o sentido da piada por não fazermos parte daquele grupo social. Isto ocorre porque, como nos diz Bergson (2001, p. 5), "por mais franco que o suponham, o riso esconde uma segunda intenção de entendimento, eu diria quase de cumplicidade, com outros ridentes, reais ou imaginários". A fim de compreendermos então o fenômeno da comicidade, seria imprescindível localizá-la em seu lugar de origem, a sociedade. A associação de pessoas em grupos fechados é o seio de onde brotará o riso cômico. E mais ainda, uma situação cômica nascerá quando tais indivíduos reunidos decidirem direcionar sua atenção a um deles de maneira momentaneamente insensível. Mas qual seria a motivação desse gesto? Possuiria o riso uma função prática nas sociedades fechadas? Como o ato de rir poderia contribuir para a manutenção de certa ordem ou costumes?

De um modo geral, Bergson dirá n'O riso que situações cômicas surgem do desajuste. E o desajuste pode se mostrar, por exemplo, no mau jeito corporal em contornar situações cotidianas as mais diversas, tais como a incapacidade de um transeunte para ultrapassar um obstáculo em seu caminho, o que o levará inevitavelmente à queda e, portanto, ao riso da assistência (BERGSON, 2001, p. 7). O hábito corporal automatizado talvez o tenha impossibilitado de realizar um movimento inesperado, ou mesmo certa desatenção à situação

\footnotetext{
${ }^{9}$ Em 1905, Sigmund Freud declarou em seu livro $O$ chiste e sua relação com o inconsciente ter sido "seduzido" pelas ideias de Bergson relativas à comicidade. Naquela obra, Freud trata de um expediente, o chiste, fabricado com a intenção do ganho de prazer que pode, ou não, levar ao riso cômico. Entre os motivos da produção do chiste, Freud cita o fator social envolvido no processo psíquico do ganho de prazer. Para este ocorrer, necessita de audiência. O chiste precisa ser comunicado e, além disso, compreendido: "[...] ninguém pode se contentar em fazer um chiste apenas para si mesmo. O impulso de comunicar o chiste está inseparavelmente ligado ao trabalho do chiste" (FREUD, 2017, p. 204). Assim como o riso cômico só surge no seio de um grupo que compartilha um modo de vida, uma cultura, "cada chiste demanda assim seu próprio público, e rir dos mesmos chistes é uma prova de grande compatibilidade psíquica" (FREUD, 2017, p. 215).
} 
presente. O filósofo denomina esse desajuste como uma rigidez mecânica do corpo quando a situação exige flexibilidade. Temos aí um exemplo de comicidade superficial, acidental, que pode ocorrer a qualquer um.

Para além dessa comicidade externa, haveria uma mais interiorizada na personalidade de indivíduos distraídos. Não nos parece cômica, por exemplo, uma pessoa "naturalmente" desatenta? Ela age "[...] como uma melodia atrasada em relação ao acompanhamento", ela se adapta "[...] a uma situação passada e imaginária quando seria preciso moldar-se pela realidade presente" (BERGSON, 2001, p. 8). A personalidade distraída é descrita n'O riso como a de um sonâmbulo, "suas ações são distrações". O sonâmbulo ou sonhador parece transitar no mundo dos despertos apenas forçosamente, é no mundo dos sonhos onde gostaria de permanecer; como, por exemplo, em uma ilusão literária, crendo-se poder viver a vida de um personagem de histórias fantásticas. O sonâmbulo se distrai da realidade concreta, e possui uma ideia fixa: desejaria de fato poder viver nesse mundo imaginário (BERGSON, 2001, p. 9-10).

Além da distração natural, há outro tipo de desajuste que é muitas vezes alvo de riso na sociedade, o vício. Aparentemente não haveria nada mais dramático para um ser humano do que nutrir vícios, haja vista a privação de sua liberdade em função de hábitos autodestrutivos. No entanto, é comum em obras cômicas a descrição de um personagem por seu vício. Em tais contextos, o vício cômico ressalta a personalidade inteira da pessoa simplificando o personagem, vejam-se os casos de $O$ avarento, de Molière, e d'O jogador, de Dostoievski. Segundo Bergson (2001, p. 11), o que torna esses personagens cômicos é ainda o automatismo de suas ações, a reincidência em comportar-se dessa ou daquela maneira, mesmo contra todas as advertências.

Eis aí também um ponto central na discussão estética de Bergson em torno da distinção entre a arte cômica e a arte trágica. De acordo com o filósofo, o drama, diferentemente da comédia, internaliza os vícios ao personagem ao ponto em que este não possa ser reduzido ao seu vício. O personagem trágico é carregado de complexidade psicológica, o que a comédia deixaria escapar, como está claro na seguinte passagem d'O riso:

Se eu pedir ao leitor que imagine uma peça chamada $O$ ciumento, por exemplo, ao seu espírito acudirá Sganarelle, ou George Dandin, mas não Otello; $O$ ciumento só pode ser título de comédia. É que o vício cômico pode unir-se às pessoas tão intimamente quanto se queira, mas nunca deixará de conservar existência independente e simples; continua sendo personagem central, invisível e presente, do qual as personagens de carne e osso ficam suspensas em cena. (BERGSON, 2001, p. 11-12, grifos do autor)

Se o personagem cômico procura corrigir sua postura diante da sociedade a fim de sanar o riso repreensivo dos outros, um personagem trágico, por sua vez, “[...] não mudará em nada 
a sua conduta ao saber que a julgamos; poderá perseverar nela, mesmo com a plena consciência do que é, mesmo com o sentimento nítido do horror que nos inspira" (BERGSON, 2001, p. 12). A comédia representa, por exemplo, gêneros, tipos, ao passo que a tragédia, indivíduos. Daí a ligação da comédia com a inteligência, faculdade que, entre outras funções, generaliza e simplifica a vida.

Ainda no terreno da distração, o automatismo é irmão do riso, donde a noção de que a figura cômica não se saiba como tal. O cômico, dirá Bergson (2001, p. 12), é inconsciente. Ninguém parece desejar ser motivo de chacota ou escárnio na sociedade da qual é parte. O portador de um vício cômico, por exemplo, quando em situações constrangedoras, ou seja, quando alertado de seu desajuste pelo riso dos outros, buscará corrigir-se, ainda que por fingimento. Eis então a afirmação bergsoniana crucial que declara o riso como um gesto social eficaz: "Podemos dizer desde já: é nesse sentido, sobretudo, que o riso 'castiga os costumes'. Ele nos faz tentar imediatamente parecer o que deveríamos ser, o que sem dúvida acabaremos um dia por ser de verdade" (BERGSON, 2001, p. 13).

O sonhador, o distraído, o viciado são socialmente desajustados. O desajustado é indesejável nas sociedades fechadas, ele representa a inadequação à moral aceita, um ser que não absorveu as imposições sociais e morais do convívio coletivo completa ou parcialmente. Seu exemplo será um perigo, uma ameaça, porque seu "eu social", por distração ou deliberadamente, não se rendeu à pressão ou ao hábito, e por isto mesmo deverá ser repreendido. Como afirmou Bergson n'As duas fontes, “uma infração da ordem social reveste-se assim de um caráter antinatural: ainda que se repita com frequiência, induz em nós o efeito de uma exceção que estaria para a sociedade como um monstro está para a natureza" (BERGSON, 2005, p. 26).

Para funcionar segundo seu esquema de fechamento, a sociedade deverá então criar mecanismos de contenção das exceções. Aqui é o riso que aparece como ferramenta punitiva branda, castigando costumes desviados. Lá na obra de 1932 é a religião estática, pronta a nos submeter ao que a sociedade espera e exige de nós com a promessa de uma recompensa no além pelo "bom" comportamento em vida. Eis, portanto, a ligação direta do riso punitivo que aparece como gesto social no ensaio de 1900 com a moral e a sociedade fechadas descritas anos mais tarde n'As duas fontes. 


\section{Sociedade e mal estar: uma aproximação entre Bergson e Freud}

Atenção redobrada ao presente e elasticidade para contornar os obstáculos que ameacem atrapalhar a engrenagem do corpo social (BERGSON, 2001, p. 13), tais seriam as duas "forças complementares" atuando intermitentemente no fluir da vida. Essa "tensão" ou "atenção" dirigida ao presente, à situação atual, fora já apresentada por Bergson em Matéria e memória (1999), sob o nome de percepção concreta (BERGSON, 1999, cap. 1), um recorte da realidade que visa realizar o presente da maneira mais prática possível. "Perceber conscientemente significa escolher, e a consciência consiste antes de tudo nesse discernimento prático" (BERGSON, 1999, p. 49).

Não obstante essa característica pragmática, a percepção consciente carrega em si lembranças acumuladas inconscientemente, prontas a revigorar-se desde que a situação presente o solicite. As lembranças-imagens seriam então capazes de nos auxiliar no presente conduzindo de maneira prática nossa ação sobre a matéria. Sendo assim, estar desperto e atento à vida é estar ligado pela percepção à situação presente. A elasticidade que a experiência demanda de nós, lado a lado com aquela tensão corporal, seria o ponto chave da adaptação humana às situações imprevisíveis que ocorrem no fluxo da duração. A convivência social equilibrada dependerá da atuação dessas duas forças em nosso corpo, espírito e caráter (BERGSON, 2001, p. 13-14).

Além de tudo isso, equilíbrio corporal, espiritual e moral, a sociedade ainda exigirá de nós uma vida boa: "uma vez afastadas todas essas inferioridades que dizem respeito ao lado sério da experiência [...], a pessoa pode viver, e viver em comum com outras pessoas. Mas a sociedade exige outra coisa ainda. Não lhe basta viver; ela faz questão de viver bem" (2001, p. 14). Seus membros não deverão apenas se conformar às normas automaticamente, deverão se sentir bem ao fazê-lo, sendo felizes ao seguir as regras do jogo social. No que concerne ao tema da felicidade, valerá a pena trazermos à luz alguns conceitos freudianos em fina sintonia com as ideias de Bergson apresentadas tanto n'O riso quanto n'As duas fontes.

No livro $O$ mal-estar na civilazação, Freud investiga o interesse humano em dar finalidade à própria vida. E esta finalidade será denominada "felicidade". A questão é: como a vida no corpo social poderia garantir felicidade a seus membros? Tanto Bergson quanto Freud concordam que a sociedade e, de um modo geral, a civilização, traz consigo benesses inquestionáveis, porém com elas há sempre o peso do compromisso com a norma, ou seja, o peso da obrigação moral. No coração da coletividade e em cada indivíduo particular, o que todo 
ser humano parece buscar é a satisfação, o prazer, a felicidade; embora a civilização jamais tenha permitido aos seus alcançá-la de fato.

Mas na sociedade constituída de modo fechado, para usarmos a terminologia bergsoniana, a ideia de uma vida feliz só se realiza de modo esporádico. Ao contrário, por toda parte a infelicidade reina, o sentimento de mal-estar social, o desprazer com a vida coletiva é experimentado mais frequentemente que a alegria. As principais fontes desse desprazer, Freud (2014, p. 31) afirma serem duas: nossa própria decadência corporal, isto é, o implacável fluxo da duração evidenciado diuturnamente em nossa própria imagem, e o sofrimento decorrente das relações que nutrimos com nossos semelhantes. Assim, o "princípio do prazer" cede lugar ao "princípio da realidade", que consiste antes na fuga do desprazer, uma vez seja tão difícil, quase impossível, alcançar a felicidade plena neste mundo.

Nessa busca incessante por uma vida feliz, e em vista de uma grande recompensa para o "bom comportamento", muitos se submetem a privações de toda ordem. A proliferação das religiões é um bom exemplo disso. Por outro lado, lampejos de felicidade poderão ser encontrados em outras formas de fuga do real que não a religião, a saber: o consumismo, o interesse mórbido pela "felicidade" alheia, tão facilmente exposta nas redes sociais, o abuso de substâncias entorpecentes, apenas para citar alguns exemplos. Quando tais métodos não satisfazem, todos os transtornos psicológicos que afetam o mundo contemporâneo vêm à tona: neuroses, depressão, fobias, ansiedade. Tudo isso porque "aquilo que chamamos 'felicidade', no sentido mais estrito, vem da satisfação repentina de necessidades altamente represadas, e por sua natureza é possível apenas como fenômeno episódico" (FREUD, 2014, p. 30-31).

Como afirma Freud n'O futuro de uma ilusão, "é digno de nota que os seres humanos, embora incapazes de viver no isolamento, sintam como um fardo os sacrifícios que a civilização lhes requer, para tornar possível a vida em comum" (FREUD, 2014a, p. 234). A busca pela felicidade então nada mais é que a tentativa de livrar-se desse fardo. Mas não há como livrarse dele, afinal escolhemos a vida coletiva. Por isto, a fim de prevenir-se contra "revoltas" e manter as normas estabelecidas, a sociedade fechada encontrará seus mecanismos de repressão e coação, pois "[...] a civilização tem de ser defendida contra o indivíduo, e todos os seus regulamentos, instituições e decretos são postos a serviço dessa tarefa" (FREUD, 2014a, p. 234).

Freud percebeu logo cedo em sua metapsicologia que "[...] em todos os seres humanos se acham essas tendências destrutivas, antissociais e anticulturais, e de que estas, em grande número de pessoas, são fortes o bastante para determinar sua conduta na sociedade humana" 
(2014a, p. 235). Afinal, como bem disse Bergson (2005, p. 25), "uma sociedade humana é um conjunto de seres livres". E a liberdade é um elemento que volta e meia se apresenta a contrariar o que está socialmente posto. Porque, independentemente do que seja necessário para a coletividade e para a satisfação dos padrões morais aos quais esta se submete, a coletividade é composta por sujeitos com desejos próprios. A impossibilidade da realização desses desejos é geradora de conflitos internos, psíquicos, mas também externos, sociais. Deste modo, ainda que a moral fechada se imponha contundentemente entre os membros de uma comunidade, tendências particulares de cada um podem, em algum momento, se sobrepor aos anseios de ordem e moralidade dogmaticamente impostos.

Sendo assim, na sociedade ideal, toda atitude extrema será reprimida porque não nos bastará viver integrado ao modelo social correto, a sociedade espera algo mais de nós. O comportamento flexível ao extremo será coibido, mas o rigor excessivo também. Exige-se de nós tensão e flexibilidade na justa medida, o contrário disso poderá soar como falta ou excesso, isto é, como um comportamento excêntrico. As excentricidades não são bem vindas na sociedade fechada. Está claro no seguinte fragmento d'O riso:

\begin{abstract}
O que ela [a sociedade] deve temer também é que os membros de que se compõe, em vez de visarem a um equilíbrio cada vez mais delicado de vontades que se insiram cada vez mais exatamente umas nas outras, se contentem com respeitar as condições fundamentais desse equilíbrio: um acordo prévio entre as pessoas não lhe basta, ela desejaria um esforço constante de adaptação recíproca. Toda rigidez do caráter, do espírito, e mesmo do corpo será então suspeita para a sociedade, por ser o possível sinal de uma atividade adormecida e também de uma atividade que se isola, que tende a afastar-se do centro comum em torno do qual a sociedade gravita, de uma excentricidade enfim. (BERGSON, 2001, p. 14)
\end{abstract}

Quão difícil será a tarefa de nos enquadrarmos no modelo ideal de civilização. O “eu social", ante seus interesses e desejos pessoais, recuará da ação deliberada pela liberdade de sua vontade apenas na medida em que tema alguma instância punitiva. Como dissemos antes, n'As duas fontes uma forte aliada da sociedade e moral fechadas é a religião estática. ${ }^{10}$ Ela cumpre um papel bem específico para a manutenção dos dogmas e tabus, úteis à contenção de atitudes muitas vezes autodestrutivas. Mas aqui o aliado será outro. Uma vez que a repressão não possa ser material, desde que o desajustado não esteja afetando materialmente a ordem, ela virá através do gesto punitivo sutil do riso:

Pelo medo que inspira, o riso reprime as excentricidades, mantém constantemente vigilantes e em contato recíproco certas atividades de ordem acessória que correriam

\footnotetext{
${ }^{10}$ Para um aprofundamento acerca da noção de religião estática, conferir o segundo capítulo de As duas fontes da moral e da religião.
} 
o risco de isolar-se e adormecer; flexibiliza enfim tudo o que pode restar de rigidez mecânica na superfície do corpo social. O riso, portanto, não é da alçada da estética pura, pois persegue (de modo inconsciente e até imoral em muitos casos particulares) um objetivo útil de aperfeiçoamento geral (BERGSON, 2001, p. 15).

Talvez o riso enquanto gesto punitivo retire sua eficácia justamente do fato de que, enquanto corrige, também gera ganho de prazer, um bem estar momentâneo tanto para quem o produz quanto para quem ri, jamais para quem é objeto do riso, ou seja, aquele que está sendo punido.

\section{O riso denuncia a mecanização da vida}

Conforme a análise bergsoniana, então, o riso será uma ferramenta fundamental para a sociedade que visa manter equilibrados os papéis a serem exercidos por seus membros. Mas se a tomarmos como um "ser vivo" (BERGSON, 2001, p. 33), não deixaremos de notar que a sociedade se comporta tal qual um indivíduo "fantasiado", "mascarado". Tal imagem é, para nós, certamente risível, afinal "[...] essa ideia se forma logo que percebemos o que há de inerte, de pronto, de confeccionado enfim, na superfície da sociedade viva" (BERGSON, 2001, p. 33). Com efeito, cada situação demandará uma fantasia diversa, a qual deverá possuir caimento perfeito em quem a veste.

Mas máscaras e fantasias são vestes fabricadas, prontas. A vida, no entanto, segue seu fluxo, sua flexibilidade interior. Será então essa sensação de artifício mais uma fonte da comicidade no âmbito social. Daí Bergson afirmar que a arte cômica estabelece um vínculo estreito com a vida na medida em que a sociedade demanda de seus membros certa teatralização sem a qual o convívio estaria prejudicado. Muitas são as situações cerimoniosas, formais, às quais devemos nos submeter se pretendemos jogar o jogo social e nas quais o cômico também pode brotar desde que, por um esforço imaginativo, desvinculemos tais circunstâncias de seu aspecto grave (BERGSON, 2001, p. 33). Um casamento, uma formatura, um julgamento, uma plenária, e até mesmo um velório, são todos atos formais, exigências sociais que podem rapidamente se tornar cômicas para quem as assiste, uma vez que sua atenção se volte não para o conteúdo dessas cenas, mas para sua forma.

Contudo, em eventos cerimoniosos, o riso não é um gesto social aceitável, dada a gravidade das circunstâncias. Sendo assim, nestes contextos, seria mesmo prudente reprimi-lo a fim de que aquele que ri não passe por excêntrico, desajustado, e esteja suscetível a outras formas de punição mais desagradáveis até do que a pilhéria pública. Por outro lado, correndose o risco da punição, o riso nasce aí ainda como crítica social, como denúncia do 
comportamento mecânico e irrefletido dos indivíduos na sociedade. Ora, certo caráter mecânico, e, poderíamos dizer, artificial das ações humanas nos fazem rir. Da "[...] simples distribuição de condecorações até uma seção de tribunal. São formas e fórmulas, molduras prontas onde a comicidade se inserirá" (BERGSON, 2001, p. 34).

Bergson (2001, p. 34) parte dessa observação para descrever a fórmula geral da comicidade, a saber: o cômico nasce de um mecanismo sobreposto à vida. Convenhamos que um ato formal milimetricamente calculado pareça totalmente mecânico, não espontâneo. O que seria mais oposto à duração? Numa cerimônia qualquer, os envolvidos aparentam enfim comportarem-se como marionetes. Não seria também assim com as outras situações da vida em sociedade? Mesmo naquelas em que julgamos agir livremente? Dirá o filósofo: “[...] automatismo perfeito será, por exemplo, o do funcionário que funciona como simples máquina, ou ainda a inconsciência de um regulamento administrativo que se aplica com fatalidade inexorável e é tido por lei da natureza" (BERGSON, 2001, p. 34).

A vida então se desumaniza e passa a ser regulada segundo mecanismos artificiais, socialmente criados para fins específicos. O mecânico se sobrepõe ao vivo. O sujeito que se entrega automaticamente a uma função se distrai do vivido, reificando-se. Pois se a vida é espontaneidade, aquele que "vive" de maneira robótica não pode estar de fato vivendo, como diz claramente Bergson (2001, p. 65):

[...] se os homens estivessem sempre atentos à vida, se constantemente retomassem contato com o próximo e também consigo, nada pareceria jamais ser produzido em nós por molas ou cordinhas. A comicidade é esse lado da pessoa pelo qual ela se assemelha a uma coisa, aspecto dos acontecimentos humanos que, em virtude de sua rigidez de um tipo particular, imita o mecanismo puro e simples, o automatismo, enfim, o movimento sem a vida. Exprime, portanto, uma imperfeição individual ou coletiva que exige correção imediata. $O$ riso é essa correção. $O$ riso é certo gesto social que ressalta e reprime certa distração especial dos homens e dos acontecimentos.

O riso que a percepção dessa sobreposição faz brotar é crítico, mas o mesmo riso poderá ser reprimido pela mesma sociedade que lhe dá lugar. Assim, podemos sempre indagar: em que medida exigir de seus membros que se mantenham equilibradamente atentos e flexíveis às necessidades da vida prática não seria também uma atitude imoral, risível? Comportar-se segundo a norma não seria também algo cômico, se observarmos a sociedade de uma perspectiva dita "excêntrica"? Até que ponto, então, a coesão social será mais importante que os desejos de cada indivíduo? ${ }^{11}$

\footnotetext{
${ }^{11}$ Estas não são questões aludidas n' $O$ riso por Bergson, embora sejam algumas das que nos intrigam nesse estudo.
} 
Como ressaltamos no início de nossa discussão, segundo Bergson a comicidade dirigese à inteligência pura. A emoção se cala diante do cômico e uma passagem do terceiro capítulo d'O riso é bastante esclarecedora sobre isso:

É preciso que cada um de seus membros [da sociedade] fique atento para o que o cerca, que se modele de acordo com o ambiente, que evite enfim fechar-se em seu caráter assim como numa torre de marfim. Por isso, ela faz pairar sobre cada um, senão a ameaça de correção, pelo menos a perspectiva de uma humilhação que, mesmo sendo leve, não deixa de ser temida. Essa deve ser a função do riso. Sempre um pouco humilhante para quem é seu objeto, o riso é de fato uma espécie de trote social. (BERGSON, 2001, p. 101)

Esta tese apresentada em 1900 está em perfeita conexão com o rigor de uma sociedade fechada, tal como descrita n'As duas fontes, sempre atenta aos deslizes que seus membros possam vir a cometer. Mas o curioso é que n'O riso Bergson é cristalino ao afirmar que as normas veladas da sociedade não são necessariamente as normas da moralidade estrita. Ou seja, nem sempre os indivíduos de moral ilibada estarão dentro do modelo social desejável. Por exemplo, um viciado será tão punido pelo riso cômico quanto um virtuoso em uma sociedade de corruptos. Assim sendo, andar em dia com a moral não significa andar em dia com a sociedade (Cf. BERGSON, 2001, p. 103). Um defeito se tornará risível não em função de sua imoralidade, mas antes em função de sua insociabilidade. Deste modo, todo comportamento que venha a abalar o bom funcionamento do organismo social deverá ser posto sob suspeita, não importando que seja moral ou imoral, justo ou injusto, certo ou errado. ${ }^{12}$

É, portanto, uma lógica classificatória e generalizante que o gesto social do riso punitivo parece revelar. No seio do corpo social essa lógica poderá ser utilizada de maneira cruel e injusta (SIBERTIN-BLANC, 2011, p. 72-73) quando busca padronizar o "desajustado" e repelir a originalidade sob o olhar suspeito para o que é dito excêntrico, sonambúlico, desviado. Esse é um traço característico dos seres inteligentes, qual seja, generalizar. Como disse Bergson n'O riso, "[...] não vemos as coisas mesmas; limitamo-nos, no mais das vezes, a ler etiquetas coladas sobre elas" (2001, p. 114). Agimos assim por necessidade, na maioria das circunstâncias práticas. Mas no que tange às questões essenciais, as questões morais, uma lógica distinta deveria se impor, pois os problemas humanos fundamentais não se resolvem a partir da superfície.

\footnotetext{
12 Exemplos atuais desse tipo de situação não nos faltam. Encontramo-los amplamente difundidos na sociedade brasileira, sociedade esta que estranhamente passou, como num passe de mágica, a deslegitimar o conhecimento, a ética, a tolerância e a liberdade.
} 


\section{Considerações Finais: $O$ riso ontem e hoje}

A fim de localizarmos o contexto histórico da reflexão bergsoniana sobre a comicidade, seguiremos a análise do historiador George Minois, em seu livro História do riso e do escárnio (2003), apenas no tocante ao momento em que brotam as ideias sociais de Bergson. O riso tem lugar no final do século XIX, contraditoriamente um período nada feliz para a humanidade (MINOIS, 2003, p. 511). Mas talvez seja justamente este o ambiente propício à emergência do riso cômico, o riso corretivo. Não à toa, há toda uma filosofia do riso que emana nesse período histórico. Bergson não foi o único pensador a se debruçar sobre o tema da comicidade. "Não há filósofo importante que não tenha abordado esse problema no século XIX, sinal da ascensão do riso à categoria dos comportamentos fundamentais" (MINOIS, 2003, p. 511).

Antes de Bergson, e no mesmo século, Hegel, Kierkegaard, Schopenhauer e Nietzsche abordaram o tema, cada um a seu modo e em contextos distintos. Hegel repudiou a ironia. Em seu Curso de estética, pretendeu "[...] restabelecer a seriedade, isto é, a crença no caráter essencial das coisas" (MINOIS, 2003, p. 512). ${ }^{13}$ Kierkegaard, por sua vez, atribuiu mais valor ao humor do que Hegel. A ironia é vista por ele em sentido socrático, ela é metódica, auxilia o filósofo na passagem do estágio estético para o ético. "O humor é, assim, via de acesso à seriedade absoluta, Deus" (MINOIS, 2003, p. 514). Já Schopenhauer demonstrou um grande interesse pelo riso, ainda que defendesse uma visão de mundo pessimista. O filósofo dedicou muitas páginas de seu livro $O$ mundo como vontade e como representação a uma análise do mecanismo do riso (MINOIS, 2003, p. 515). De acordo com Minois (2003, p. 517),

Schopenhauer tem consciência de viver em um mundo que já é 'humorístico', isto é, onde todos riem de qualquer coisa e cuja hilariedade é expressão de idiotice. $\mathrm{O}$ riso autêntico é aquele do filósofo que constata o nonsense da vida confrontado à vontade de viver $[\ldots]$.

Na esteira de Schopenhauer, Nietzsche (Apud MINOIS, 2003, p. 518) acreditava ser o riso um "remédio contra a vida". Toda a obra desse filósofo é perpassada por uma compreensão do riso como antídoto contra a moral cristã. "O riso e o pessimismo caminham juntos, entretêm-se mutuamente. É porque tomamos consciência de nossa condição desesperada que podemos rir seriamente, e esse riso nos permite suportar essa condição" (MINOIS, 2003, p. 519).

\footnotetext{
${ }^{13}$ De alguma maneira, Bergson concordaria com essa visão hegeliana, já que, quando afirma ser a comédia uma arte menor justamente por sua funcionalidade social, por seu caráter satírico, atribui maior valor à seriedade dramática da tragédia (BERGSON, 2001, Cap. 3).
} 
Precedida por esse histórico filosófico de investigação do riso, a obra de Bergson vem à luz em meio a uma polêmica. Na segunda metade do século XIX, além de filósofos, muitos autores demonstram interesse pelo tema. Teorias afloram de todos os campos do conhecimento: psicologia, sociologia, fisiologia. ${ }^{14}$ Em comum, essas interpretações acerca do riso e do cômico teriam a influência do positivismo da época, lidando com a questão a partir de uma perspectiva por vezes demasiado cientificista, psicofisiológica. Daí Bergson buscar uma interpretação alternativa do riso como um gesto social. Ante esse mar de estudos sobre o mesmo objeto, $O$ riso é recebido com reações diversas. É Criticado como reducionista por James Sully, em 1902, discípulo de Hebert Spencer, e, no mesmo ano, mas sem citar Bergson, por Dugas em sua Psicologia do riso, quando põe em xeque a tentativa dos filósofos de entender a todo custo o significado do riso, o que, segundo ele, permaneceria inexplicável (MINOIS, 2003, p. 521-522).

Não obstante estas críticas, Bergson estava atento para o fato de que o riso como ferramenta de ajuste social parece ser uma faca de dois gumes. Afinal, pode servir tanto à manutenção da ordem quanto como denúncia de uma "ordem" que precisa ser alterada. Por outro lado, poder-se-ia contra-argumentar que a compreensão do riso apenas como um gesto social corretivo equivaleria a um reducionismo cego, afinal a comédia deveria ser valorizada como forma de arte genuína, independentemente de seu potencial social. Além disso, o riso cômico é fonte de prazer, tanto para quem produz, quanto para quem ri (e quase nunca para quem é objeto do riso). Entendido assim, o riso seria também uma das muitas formas de fuga do real. ${ }^{15}$

Freud, por exemplo, em seu ensaio de 1905, O chiste e sua relação com o inconsciente, interessou-se pelo humor em vista de compreender porque este é fonte de ganho de prazer para os seres humanos. Mas, assim como Bergson, Freud também percebeu que o humor possui um componente social muito forte, ainda que não no mesmo sentido atribuído pelo filósofo francês. ${ }^{16}$ Freud leu $O$ riso e declarou concordar com a tese, segundo ele "sedutora", de que o cômico surja em decorrência, sobretudo, da mecanização do vivo. O pai da psicanálise interpretou o texto bergsoniano e aprofundou alguns temas não explorados n' $O$ riso, já que este livro se restringiu à comicidade apenas como gesto social. Embora Bergson tenha percebido a

\footnotetext{
${ }^{14}$ George Minois (2003, p. 521-522) cita diversos autores e obras sobre o riso publicadas na mesma época em que Bergson se interessa pelo tema, quais sejam: ROY, Sobre o riso (1814); MICHIELS, Ensaio sobre o talento de Regnard e sobre o cômico em geral (1854); DUMONT, Causas do riso (1862); BAIN, As emoções e a vontade (1885); SPENCER, Fisiologia do riso (1891).

${ }^{15}$ Sobre isso, indaga George Minois (2003, p. 19): “o riso não é o único meio de nos fazer suportar a existência, a partir do momento em que nenhuma explicação parece convincente?”.

${ }^{16}$ Vale conferir o capítulo intitulado "Os motivos do chiste. O chiste como processo social".
} 
relação da comicidade com algo de inconsciente, foi o austríaco quem de fato levou a fundo essa relação n' $O$ chiste.

O que interessa mesmo a Bergson, como vimos, é o componente social da comicidade. E, embora 32 anos separem os dois livros que aqui aproximamos, $O$ riso e As duas fontes da moral e da religião, é clara a relação que nutrem no que diz respeito ao olhar aguçado para a sociedade. De 1900 a 1932, a sociedade fechada continuou exigindo de seus membros determinados comportamentos, obediência a valores estabelecidos em torno da manutenção de uma ordem que beneficiasse à coletividade. Mas do século XX ao XXI, dos dias de Bergson aos nossos, o riso continua tendo um lugar reservado na sociedade. Como bem notou Minois, “o riso foi o ópio do século XX, de Dadá aos Monty Pythons. Essa doce droga permitiu à humanidade sobreviver a suas vergonhas" (MINOIS, 2003, p. 553).

Não há mais lugar para os tristonhos na civilização contemporânea, rir é fazer parte, é estar inserido ao grupo. O riso agora, além de ferramenta de ajuste é também mecanismo de inclusão. "Do mundo político aos meios de comunicação e do colégio ao clube da terceira idade, manter o cômico é inevitável. O humor universal, padronizado, midiatizado, comercializado, globalizado, conduz o planeta" (MINOIS, 2003, p. 554). É preciso rir para se estar encaixado ou padronizado no sistema de hábitos e obrigações compartilhados na "sociedade humorística". Assim sendo, as questões apontadas n'O riso podem e devem, sem dúvida, nos ajudar a entender essa sociedade contemporânea e seus mecanismos intelectualmente forjados de controle, exclusão e inclusão.

Pela riqueza de temas que aborda, por sua relação com o contexto geral do bergsonismo, $O$ riso merece ocupar um lugar relevante no rol das obras de Bergson. Não apenas relativamente às reflexões de cunho estético, mas, sobretudo, no âmbito das questões morais que serviram de base para um aprofundamento mais elaborado n'As duas fontes. Como visto, à época de Bergson o riso, a comicidade, a ironia eram objeto de muito interesse por parte da comunidade intelectual. Hoje não é diferente, o tema continua intrigando as mentes de pensadores de todas as áreas. Porém, não obstante todos esses estudos, acreditamos que $O$ riso ainda seja uma fonte relevante para compreendermos o lugar do cômico em nossa sociedade, além das outras possibilidades de interpretação que essa obra guarda. 


\section{REFERÊNCIA BIBLIOGRÁFICAS}

BERGSON, H. O riso. São Paulo: Martins Fontes, 2001.

BERGSON, H. As duas fontes da moral e da religião. Coimbra: Almedina, 2005.

BERGSON, H. A evolução criadora. São Paulo: Martins Fontes, 2005a.

BERGSON, H. Matéria e memória. São Paulo: Martins Fontes, 1999.

FENEUIL, A.; WATERLOT, G. Bergson, philosophe de l'émotion. Présentation du dossier. In: FRANÇOIS, A.; RIQUIER, C. Annalles bergsoniennes VIII. Bergson, La morale, les émotions. Paris: PUF, 2017, p. 51-60.

FREUD, S. O chiste e sua relação com o inconsciente. In: FREUD, S. Obras completas, Vol. 7, São Paulo: Companhia das Letras, 2017.

FREUD, S. O mal-estar na civilização. In: FREUD, S. Obras completas, Vol. 18, São Paulo: Companhia das Letras, 2014.

FREUD, S. O futuro de uma ilusão. In: FREUD, S. Obras completas, Vol. 17, São Paulo: Companhia das Letras, 2014a.

MINOIS, G. História do riso e do escárnio. São Paulo: UNESP, 2003.

SCHICK, J. F. M. Intuition et émotion: une relation méconnue. In: FRANÇOIS et RIQUIER. Annalles bergsoniennes VIII. Bergson, La morale, les émotions. Paris: PUF, 2017, p.141-167.

SIBERTIN-BLANC, G. Le rire comme um fait social total (élements de sociologie bergsonienne). In: WORMS, F; RIQUIER, C. Lire Bergson. Paris: PUF, 2011, p. 61-80. 